scarcity in the one case and of labor needs in the other. It is an excellent ethnographic comparative analysis, but its relation to the book's central topic is marginal. Nicholas Tapp, working from a dependency perspective, examines development projects among the Hmong in Thailand, showing how historical peripheralization of the Hmong was defined by many of the same external economic and political forces that gave rise to the national boundaries of the Thai state. The political and cultural status of the Hmong in Thailand, and the failure of various development projects, was determined by many of the same historical forces that produced the peripheralization that was in part being addressed by the development projects. In summary, although several of the contributions are valuable, they are somewhat uneven, and the book doesn't quite come together around the central theme indicated by the title and the editor's introduction. It is an important and difficult topic, though, and the Southeast Asian mainland is an ideal laboratory for studying it.

\title{
Forest Monks and the Nation-State: An Anthropological and Historical Study in Northeastern Thailand. By J. L. Taylor. Singapore: Institute of Southeast Asian Studies, 1993. xii + 377 pp. 6 plates.
}

\author{
Reviewed by William Galloway, University of Washington.
}

Those whose lives have been more than superficially touched by Thailand will recognize the image of wandering forest monks, "walking by themselves or in small bands in single file... patched ochreous robes the colour of burnt mustard," meditation umbrellas over their shoulders and attention focused a "plough length" ahead. Taylor's study meticulously traces the historical process by which "monks residing on the fringe of organized space and domesticated order" could be transformed into "the heart of Thai religiosity." This account will be of considerable historical value to JPE readers as the forest monks are apparently unwitting participants in their own demise, turned to instrospection as the forests of northeastern Thailand rapidly disappear. The monastic career and pupillary lineage of Ajaan Man Phuurithatto, founder of the modern "kammathaan" (ascetic meditation) forest tradition, forms the exemplary center around which Taylor's analysis unfolds.

While there have been wandering ascetics since the time of the Buddha, this type of forest monk first appears in the context of religio-political reforms integral to the process of Thai state-building during the reigns of King Mongkut (1851-68) and King Chulalongkorn (1868-1910). Taylor asserts that many such monks were "effectively frontiersmen for the nation-state in the outer provinces, caught in the nexus of prevalent social and political conditions" (136). The changing status of Man's revivified forest tradition at the periphery in relation to the still-expanding influence of the centralized Thammayut order, linked to "a pervasive patronage system with the royalty in the capital," provides the particular circumstances within which Taylor explores the universal dynamics of a doctrinal Buddhism in its most "primitive" mode of expression, "a living system of beliefs and ritual practices set in their historical and sociocultural context." 
Northeastern forest monks, in their conscious attempt to regain "the mystical source of normative religion" are seen as the cynosures of change in a traditional dialectic between theory and practice, embedded in the complex increments of reform. Historic and contemporary features of forest monasticism in Thailand are understood not as expressions of "an undifferentiated, ossified, or impervious movement" but as "segmentary pupillages sharing common features," whose existence attests to the vitality of Theravada Buddhism in Southeast Asia today. Segmentary pupillages show a distinct evolutionary trend from radical social critique to social domestication as the secluded meditator comes to be recognized as "the very image of purity through self-mastery" and so the object of "profuse patronage, especially and importantly by the royalty," in a process Taylor calls "the routinization of individuated charisma."

Paradoxically, the more a monk withdraws into the periphery, the more sought-after he becomes. Taylor traces this "clear processual pattern" through four phases from the first points of "impact" through the construction of a jedii (traditional burial mound) in memory of the teacher. Practicing meditators will have by this time "hived off elsewhere" and been replaced at the forest monastic center by "institutional" monks from the town and village.

While Taylor bemoans "the last resort... selling cheap artefacts, 'blessed water,' pictures of the deceased master, medallions, and the like," he notes that in a wider sense such popular devotions have long been a feature of Buddhist Southeast Asia, "where the landscape is potted with jedii, indigenous Buddhalogical sacra." The ecological impact of this evolutionary process is less sustainable. The northeastern forests were effectively domesticated by the early 1960s and are now disappearing at an alarming rate, together with the remaining forest monks. The implications of Thailand's entrance into the world economy and the penetration of capital and state into "these patternless distant provinces" are hauntingly clear as Ajaan Thui Chanthakaro remembers, "less than twenty years ago the forest monks' dwellings were the only cleared part of the primal forest... today the forest monastery is the only forest in the cleared surrounding countryside."Although some forest monks evince concern with matters of ecology and the environment, Taylor reports that most of his monastic informants felt that wider social, political, and economic changes, while leading to their own demise, were, as "kammic consequences," inevitable and thus "stressed introspective mental cultivation."

As the forest monk tradition reaffirmed and reinvigorated by Man fast recedes with the nation's forests and the spoiling of Man's remaining first-generation pupils through "perfervid attention from the laity," it becomes increasingly problematical and is beset with contradictions and distortions. Speculating on a conscious need for revitalization, Taylor notes that in Thailand potential reformers like Man have tended to work within the establishment, though "undoubtedly on the fringe of social acceptability," emerging "from time to time in response to particular historical conditions." The current rise of the predominantly urban and fundamentalist Santi Asoke movement springs immediately to mind. Taylor's "oral accounts, interviews... published and unpublished textual accounts... monastery histories and early tamnaan (Buddhist legendary tales)," in part collected during his own experience in the meditative vocation as a monk in 1982, have yielded a wealth of data on this modern inflorescence of the forest monk tradition.

While he claims to have assessed critically all material "along with its mode of transmission," noting in particular how "doctrinal themes are internalized, reinterpreted, and expressed by the actors," the personalities of these "actors" or "catalysts" of historical change haunting "charnel grounds" and "the taboo-loaded zone" at "the purlieu and 
interstices of social order," remain elusive. Individual practitioners, pupillages and segmentary lineages differ widely in their ability to maintain their status "at the terminus of civilization," in the world but not of the world. Taylor's detached perspective on the subjects of his study may be necessitated by respect for his informants, who justifiably fear excessive publicity and the risk of "spoiling," but this perspective gives the work its theoretical flavor, despite the attention to detail. It is widely believed that Ajaan Man, in life "an enigma to the authorities," attained release from the conventional world and entered "nipphaan" (nirvana) upon his death in 1949. His ultimate release coincided with a surge of national attention for "the old 'vagabond' monk" and "infusion into the stream of orthodoxy." A compelling image of Man, as "arahan" (saint), is the still core of this book. For the reader, this book is his jedii. The irony is that he cannot be eulogized without it.

\section{Women and Change in the Caribbean, edited by Janet $H$. Momsen. Kingston: Ian Randle; Bloomington: Indiana University Press; London: Currey, 1993. x, 320 pp.}

\section{Reviewed by Marietta Morrissey, Professor and Chair, Department of Sociology, Anthropology, and Social Work, University of Toledo, Toledo, Ohio.}

The study of women and gender in the Caribbean has quickly expanded as major works have appeared on women in slavery, in late nineteenth and twentieth century free labor forces, and in contemporary politics and economy. The Caribbean is particularly intriguing to scholars of women and gender because of Caribbean women's historically significant roles in both the economy and the domestic sphere. Moreover, women's position differs among Caribbean societies, both across major language groups (the English, Spanish, and French-speaking West Indies) and within geographically and culturally defined areas.

It is challenging to capture the range of current research and theorizing on women in the Caribbean. Janet Momsen manages to do so, however, offering a comprehensive and exciting synthesis of recent scholarship in her anthology, Women and Change in the Caribbean. Momsen is a well known geographer with extensive research experience in the eastern Caribbean. She presents eighteen articles on women's work and status in various Caribbean nations, all focusing on the contemporary era, but with many discussing Caribbean women's history as well. As Momsen suggests in her thoughtful introduction, the collection is valuable for its pan-Caribbean and multidisciplinary focus and strong base in field work. The authors criticize several traditional theoretical paradigms, including the presumed dichotomy between women's public and private roles. They offer alternative perspectives that stress women's multiple and intersecting roles and the constant interaction of race, class, and gender throughout Caribbean history. Momsen divides the articles into two major sections, one, on private and public spheres, and the second on women's economic roles.

The first section explores the relationship of women's work in production and reproduction and the intersection of domestic and community-level activities. Two essays are critical of traditional conceptual approaches that lend little to our understanding of women in the Caribbean. Besson questions the utility of Peter Wilson's dualism of "reputation and responsibility" for the study of women, presenting research on a Jamaican 